\section{5 年春季学術大会巡検趣旨}

仙台および松島周辺地域にお汀る開発の歴史において， かってこの地が明治政府の東北経営の中でどのように位置 づけられ，考えられていたかを，野蒜築港計画を例にとり， 現在の仙台港建設に至る過程を探ぐる。また仙台平野の苦 竹および品井沼干拓地においては，藩政時代から現在に至 る低湿地開発の歴史と，開発がもたらした人間生活および 自然環境への影響を，工場地区の地盤沈下の現状あるいは 品井沼の河川管理の実態をとおして見学する。こうして地 域社会の発展と地理学とのかかわりあいなどを検討したい．

(長谷浩明)

\section{日本学術会議第 66 回報告}

(日本学術会議広報委員会からの報告を短縮して作成)

第 9 期最後の総会は 10 月 $22 \sim 24$ 日の 3 日間開催された。
会長, 両副会長加らの報告の後, 提案について活発に審議. 㛯告 11, 要望 1, 申入れ 2, 声明 1 及び申合せ 3 の計 18 件 が採択された。これらは，「原子力安全の全般的な課題解決 のために (勧告)」他，国民生活に直接関る科学技術に関す る多面的な歓告・申入れ等である。

\section{4 年度秋季学術大会記事}

1974 年度秋季大会は, 10月 26 日（土） 10月 28 日（月） 3 日間, 福島県立喜多方女子高等学校 および会津地方中. 南部において，福島地理学会との合同でおこなわれた。

大会第1 日および第 2 日午前中におこなわれた 19 の研究 発表は，自然・人文の各分野にわたり，約 70 名が参加して 活発であった。なお，第1日夜には根親会がもたれ，両学 会会員相互の親睦を深为た（参加者 45 名）.

巡検は「会津地方中・南部の地形々土地利用」のテーマ で，大会第 2 日午後加第 3 日まで予定通り実施され，す こぶる有意義であった。

訂 正 第 26 巻 第 4 号 田村論文

\begin{tabular}{|c|c|c|c|}
\hline 頁 & 行 & 誤 & 正 \\
\hline 189 & 右 2 & 論緒 & 端緒 \\
\hline$"$ & 右 5 & 機械的 & 機能的 \\
\hline 190 & $\begin{array}{c}\text { Table } 1 \\
\text { 最下†記号の箇所 }\end{array}$ & below & beyond \\
\hline 193 & 左 9 & 構造 & 構成 \\
\hline$"$ & 左 18 & Fig. 2-1 & Fig. 2-2 \\
\hline$"$ & 左 20 & Fig. 2-2 & Fig. 2-1 \\
\hline$"$ & 左 28 & Fig. 2-2 & Fig. 2-1 \\
\hline " & 左 36 & 或る & 成る \\
\hline 196 & $\begin{array}{l}\text { Table } 2 \\
\text { 左 } 2 \text {, 右 } 2 \text { の欄 }\end{array}$ & throughflow & Throughflow \\
\hline$"$ & 右 6 & 知らされた & 知られた \\
\hline 198 & 注 5) & Side Slope & Side slope \\
\hline 199 & 左 10 & 岐阜林署 & 岐阜営林署 \\
\hline$"$ & 右 7 & Seci. & Sci. \\
\hline$"$ & 右 17 & Assoc. Intern. & Intern. Assoc. \\
\hline$"$ & 右 19 & Assoc. Intern. & Intern. Assoc. \\
\hline$"$ & 英文要旨 14 & agent & agents \\
\hline
\end{tabular}

